\title{
ANALISIS TINGKAT KEBERHASILAN CRYOTERAPY MENGGUNAKAN NEURAL NETWORK
}

\author{
Sri Rahayu'; Fitra Septia Nugraha ${ }^{2}$; Muhammad Ja'far Shidiq ${ }^{3}$ \\ Ilmu Komputer \\ STMIK Nusa Mandiri Jakarta \\ www.nusamandiri.ac.id \\ 1'srahayu110527@gmail.com; ${ }^{2}$ fitraseptia7@gmail.com; ${ }^{3}$ ash.shidiq.mj@gmail.com
}

\begin{abstract}
Human health is very important to always pay attention especially after someone has been declared suffering from an illness that can inhibit positive activities. One of the most feared diseases of the $20^{\text {th }}$ century is cancer. This disease requires treatment that is quite expensive. Alternative treatments are cryotherapy or ice therapy. But cryotherapy also has side effects, it is necessary to do research on its success by taking into account certain conditions of the parameters. So the purpose of this study is to analyze the success of cryotherapy so that the dataset can be used as one of the benchmarks for the success of the cryotherapy tratment method. The method used in this study is the machine learning method of Neural Network with 500 training cycles, learning rate of 0,003 and momentum 0,9 which results in a good classification of obtaining quite high accuracy of $87,78 \%$ and $A U C$ value of 0,955 .
\end{abstract}

Keywords : Cryotherapy, Machine Learning, Neural Network.

\begin{abstract}
Abstrak - Kesehatan manusia sangat penting untuk selalu diperhatikan apalagi setelah seseorang sudah dinyatakan mengidap suatu penyakit yang dapat menghambat aktifitas positif. Salah satu penyakit yang paling ditakuti pada abad ke 20 ini adalah kanker. Penyakit ini memerlukan pengobatan yang cukup mahal. Alternatif pengobatannya adalah cryotherapy atau terapi es. Namun cryotherapy juga mempunyai efek samping, perlu dilakukan penelitian akan keberhasilannya dengan memperhitungkan kondisi tertentu dari parameter yang ada. Maka tujuan penelitian ini adalah untuk menganalisis keberhasilan cryoteraphy sehingga dataset tersebut dapat digunakan sebagai salah satu tolak ukur keberhasilan metode pengobatan cryotherapy. Metode yang digunakan pada penelitian ini adalah metode machine learning Neural Network dengan training cycles 500, learning rate 0,03 dan momentum 0,9 yang menghasilkan klasifikasi baik yaitu memperoleh
\end{abstract}

akurasi cukup tinggi $87,78 \%$ dan nilai AUC sebesar 0,955.

Kata Kunci : Cryotherapy, Machine Learning, Neural Network.

\section{PENDAHULUAN}

Kesehatan manusia sangat penting untuk selalu diperhatikan apalagi setelah seseorang sudah dinyatakan mengidap suatu penyakit yang dapat menghambat aktifitas positif. Berdasarkan The World Health Report, 2005 angka kematian seseorang akibat diagnose kesehatan yang lambat serta penanganan yang buruk oleh tim medis di Indonesia mencapai 8$11 / 100.000$ populasi manusia hidup, hal ini merupakan angka yang termasuk tinggi di ASEAN. (Adil, 2005)

Pada decade terakhir abad 20 ini, kanker merupakan salah satu penyakit yang ditakuti oleh manusia pada saat ini. Hal ini seiring dengan terjadinya perubahan gaya hidup seperti makin membudayanya kebiasaan merokok, mengkonsumsi makanan yang mengandung bahan karsinogenik seperti fast food, bahan pengawet serta zat warna, dan mengkonsumsi makanan tinggi lemak; peningkatan pencemaran akibat industrialisasi dan urbanisasi; dan perubahan lingkungan berupa penipisan lapisan ozon. (Widowati \& Mudahar, 2009)

Pengobatan kanker seperti pemberian obat antikanker dan operasi tergolong sangat mahal. Selain itu, tidak jarang pasien tidak berhasil lepas dari cengkraman kanker meskipun sudah melakukan berbagai usaha pengobatan medis. (Widowati \& Mudahar, 2009). Krioterapi atau cryotherapy adalah terapi dingin, dimana tubuh akan ditempatkan dalam ruangan yang sangat dingin selama beberappa menit. (Andini, 2018) Temuan Arnott yang membekukan sel-sel kanker itu sampai suhu -18 derajat Celsius sampai -24 derajat Celsius, terbukti dapat memperpanjang umur pasien bahkan punya kemungkinan sembuh. (Aulia Adam, 2017). 
Namun, seperti kemoterapi dan metode lainnya, Cryo juga punya efek samping tergantung pada jenis kankernya. Misalnya, jika mengenai kelenjar prostat, Cryo bisa membuat pria jadi impoten. Lebih dari itu, ketelitian sangat berperan penting dalam proses cryosurgery, sebab meleset sedikit saja, maka sel kanker yang tak ikut dibekukan dapat berdampak fatal:yaitu, kembali menyebarnya sel-sel ganas itu memakan tubuh kita dari dalam. (Aulia Adam, 2017).

Teknologi, dalam perannya saat ini semakin canggih, berkembang dengan pesat dapat membantu memudahkan pekerjaan manusia dan membantu manusia dalam menentukan langkah-langkah yang harus dilakukan berdasarkan fakta yang ada. Algoritma Klasifikasi Machine Learning salah satu teknik data mining dapat membantu memprediksi keberhasilan cryoterapy berdasarkan kondisi-kondisi tertentu.

Eksperimen menggunakan klasifikasi Machine Learning pernah dilakukan oleh Ali CÜvitoğlu dan Zerrin Ișik terhadap metode pengobatan Cryotherapy dan dengan dataset imunoterapi dengan menggunakan metode Random Forest (RF) mencapai akurasi 95\%, sensitivitas 88\%, dan 98\% kekhususan. (Cüvitoğlu \& Işik, 2018). Keakuratan Imunotherapy dan cryotherapy juga pernah dibandingkan oleh Fahime Khozeimeh, Farahzad Jabbari Azad, Yaghoub Mahboubi Oskouei, Majid Jafari, Shahrzad Tehranian, Roohallah Alizadehsani, and Pouran Layegh dalam jurnalnya berjudul "Intralesional immunotherapy compared to cryotherapy in the treatment of warts" pada International Journal of Dermatology, 2017 dan menghasilkan kesimpulan bahwa Imunoterapi intralesi adalah pengobatan yang efektif. Namun, Fahime Khozeimeh,dkk menggunakan algoritma Neuro Fuzzy kepada 90 pasien dirawat dengan metode cryotherapy dengan nitrogen cair dan 90 pasien dengan metode imunoterapi menghasilkan prediksi akurasi imunoterapi 83,33\% lebih besar dibandingkan dengan cryotherapy yaitu $80,7 \%$. (Khozeimeh et al., 2017). Meski begitu, cryotherapy (terapi es) dan metode imunoterapi digunakan untuk mendapatkan hasil yang lebih cepat dan lebih murah daripada obat-obatan dan intervensi bedah untuk penyakit yang berkaitan dengan kanker, studi ini menggunakan algoritma klasifikasi yaitu Navie Bayes, pohon keputusan C4.5 dan logistik regresi yang merupakan metode klasifikasi juga. (Basarslan \& Kayaalp, 2018). Pengklasifikasian juga pernah dilakukan oleh
Wahyu Eko Susanto dan Dwiza Riana dengan mengkomparasi 3 Algoritma yaitu Neural Network, K-Nearest Neighbor dan Naïve Bayes untuk memprediksi pendonor darah yang potensial, "diketahui bahwa algoritma neural network dengan dataset RFMTC memiliki nilai akurasi paling tinggi. (Eko Susanto \& Riana, 2016).

Maka dalam penelitian ini algoritma klasifikasi machine learning yang akan digunakan adalah neural network yang bertujuan untuk memprediksi keberhasilan cryotherapy dengan mengklasifikasi 1 untuk berhasil dan 0 untuk gagal yang ditunjukkan dengan besarnya akurasi yang didapatkan setelah proses eksperimen menggunakan tools Rapid Miner, dengan terfokus pada penelitian megenai terapi es atau cryotheraphy saja, yang dilakukan dua pengujian setelah diterapkan Algoritma, pengujiannya adalah dengan confution matrix yang meguji validasi atau kebenaran antara data dengan hasil prediksi serta metode ROC (Relative Operating Characteristics) yang mnguji kehandalan model prediksi dan menampilkan Curvenya sehingga ini menjadi sebuah pembaharuan dari studi literatur yang dilakukan.

\section{BAHAN DAN METODE}

\section{Neural Network}

Neural network terdiri dari dua atau lebih lapisan, meskipun sebagian besar jaringan terdiri dari tiga lapisan : lapisan input, lapisan tersembunyi, dan lapisan output (Larose, 2005) dalam (Badrul, 2013).

Pendekatan neural network dimotivasi oleh jaringan saraf biologis. Secara kasar, neural network adalah satu set terhubung input/output unit, di mana masing-masing sambungan memiliki berat yang terkait dengannya. Neural network memiliki beberapa properti yang membuat mereka populer untuk clustering. Pertama, neural network adalah arsitektur pengolahan inheren paralel dan terdistribusi. Kedua, neural network belajar dengan menyesuaikan bobot interkoneksi dengan data, hal ini memungkinkan neural network untuk "menormalkan" pola dan bertindak sebagai fitur (atribut) extractors untuk kelompok yang berbeda. Ketiga, neural network memproses vektor numerik dan membutuhkan pola objek untuk diwakili oleh fitur kuantitatif saja (Gorunecu, 2011) dalam (Badrul, 2013). 
Prinsip pelatihan neural network menggunakan Backpropagation, untuk menggambarkan algoritma ini bahwa ada tiga lapisan algoritma Neural Network yang terdiri dari input dan output. Dimana inputnya terdiri dari dua dan outputnya hanya satu seperti ditunjukkan pada gambar dibawah. (Sucipto, 2012).

1. Inisialisasi Bobot

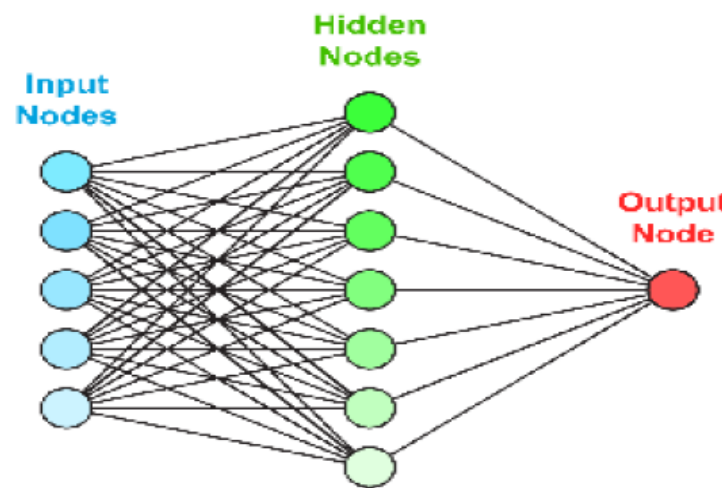

Sumber : (Sucipto, 2012)

Gambar 1. Lapisan Neural Network

2. Tiap input $\left(x_{j i} i=1,2,3, \ldots, n\right)$ menerima sinyal dari input $\mathrm{x}_{1}$ kemudian akan disebarkan kesemua unit hidden layer.

3. Masing-masing hidden layer $\left(\mathrm{Z}_{\mathrm{ji}} \mathrm{j}=1,2,3, \ldots\right.$, p) jumlah dari bobot sinyal input

$Z_{i n j}=W_{b j}+\sum_{i=1}^{n} x_{i} w_{j i}$

(1)

Sumber : (Sucipto, 2012)

4. Penjumlahan bobot sinyal masuk pada unit output, dengan menggunakan fungsi aktifasi dalam menghitung sinyal output

$y_{m}=w_{b o}+\sum_{j} w_{j o} Z_{j}$

Sumber : (Sucipto, 2012)

5. Menghitung informasi dari error

$\delta=(t-y) * f\left(y_{m}\right)$

Sumber : (Sucipto, 2012)

Menghitung bobot yang terkoreksi $\left(\mathrm{w}_{\mathrm{jo}}\right.$ baru)

$A w_{j a}=\eta \delta z_{i}$

Sumber : (Sucipto, 2012)

Menghitung bias terkoreksi

$A w_{h a}=\eta \delta$.

Sumber : (Sucipto, 2012)

6. Masing-masing unit dari Hidden $\left(\mathrm{Z}_{\pi} \mathrm{J}=1,2\right.$, ..., p)menjumlahkan delta input

$\delta_{\text {inj }}=\delta w_{j o}$

Sumber : (Sucipto, 2012)
Untuk menghitung error dikalikan dengan fungsi derivative aktifasi

$\delta_{j}=\delta_{\text {inj }} f\left(z_{\text {inj }}\right) j$

Sumber : (Sucipto, 2012)

Koreksi bobot

$W_{j i}=\delta_{j} x_{i}$

Sumber : (Sucipto, 2012)

Koreksi bias

$f w_{j b}=\delta j$

Sumber : (Sucipto, 2012)

7. Perbarui bobot dan bias

$w_{j o}($ new $)=w_{j o}($ old $)+\Delta w_{j o}$

Sumber : (Sucipto, 2012)

masing-masing unit hidden $\left(\mathrm{Z}_{\mathrm{J} 1} \mathrm{~J}=1,2,3 . ., \mathrm{p}\right)$ untuk perbarui bobot dan bias

$w_{j i}($ new $)=w_{j i}($ old $)+\Delta w_{j i}$

Sumber : (Sucipto, 2012)

Iterasi akan dilakukan diulang-ulang sampai mendapatkan nilai yang diinginkan.

Tabel 1. Setdata Olah NN

\begin{tabular}{llll}
\hline & $\mathrm{X} 1$ & $\mathrm{X} 2$ & $\mathrm{y} / \mathrm{z}$ \\
\hline 1 & 0 & 0 & 0 \\
\hline 2 & 1 & 0 & 1 \\
\hline 3 & 0 & 0 & 1 \\
\hline 4 & 1 & 1 & 1 \\
\hline \multicolumn{5}{l}{ Sumber : (Sucipto, 2012) }
\end{tabular}

Tabel diatas menggambarkan sekumpulan data yang dapat dipergunakan untuk mengajarkan algoritma neural network. Set data terdiri dari sinyal input $\left(\mathrm{x}_{1}\right.$ dan $\left.\mathrm{x}_{2}\right)$ yang dapat diolah untuk mencapai target yang diinginkan (output) $\mathrm{z}$, jaringan saraf adalah suatu proses iterative $(1$, $2,3,4)$ dimana dalam setiap iterasi koefisien bobot yang dimodifikasi menggunakan data baru dari set data pelatihan. Modifikasi dapat dihitung menggunakan algoritma yang dijelaskan pada contoh perhitungan dibawah ini.

Dimana data pada tabel diatas terdiri dari satu input layer, dengan 2 neuron (yaitu: Xi dan X2) dan hidden layer, dengan 4 neuron $(\mathrm{Z} 1, \mathrm{Z} 2, \mathrm{Z3}$ dan Z4).

Aktivasi Sigmoid:

$z=\frac{1}{1+e^{-z} \text { in }}$

Sumber : (Sucipto, 2012)

Aktivasi sigmoid untuk 1 output layer dengan neuron 
$y=\frac{1}{1+e^{y} \text { in }}$

Sumber : (Sucipto, 2012)

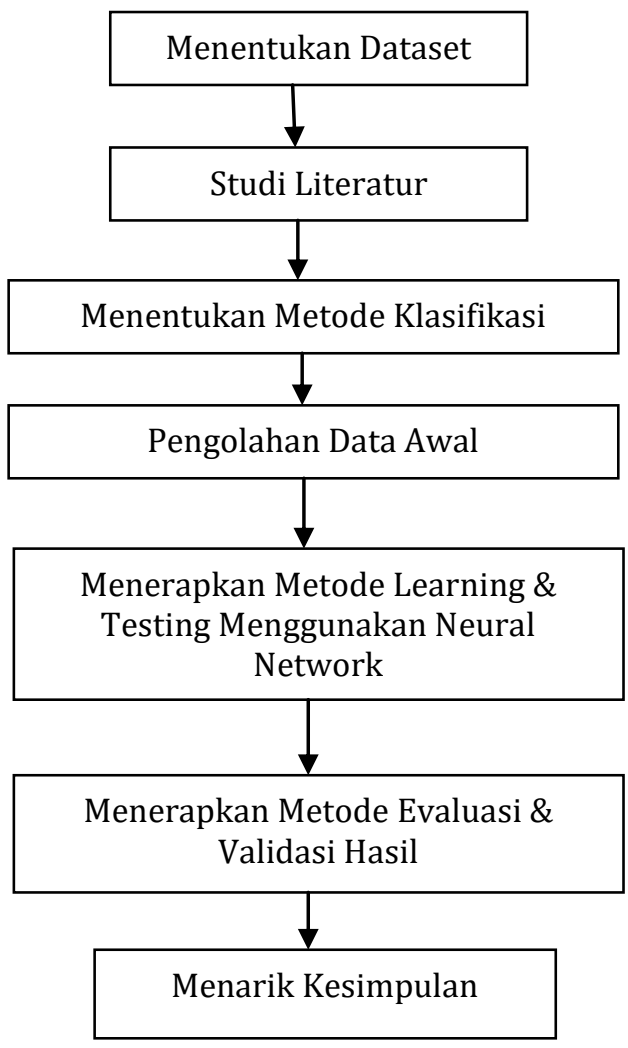

Sumber : (Rahayu, Nugraha, \& Shidiq, 2019) Gambar 2. Langkah Penelitian

Tahapan ekperimen yang dilakukan oleh penulis dalam melakukan penelitain ini ditempuh dengan berbagai kegiatan di bawah ini:

1. Menentukan Dataset

Data yang digunakan dalam penelitian ini adalah data sekunder cryotherapy yang didapatkan dari Repository UCI (Univercity California Invene) dengan alamat url : http://archive.ics.uci.edu/ml/. Dataset ini sudah berupa data yang terdiri dari atribut sex, age, time, number of warts, type, area dan class. Dengan jumlah dataset yang terkumpul sebanyak 90 data.

\section{Studi Literatur}

Langkah ini ditempuh penulis setelah memperoleh dataset, yakni dengan mencari literatur penelitian terdahulu yang berhubungan atau yang pernah menggunakan dataset yang sama, kemudian mempelajarinya, dan menjadikannya sebagai tolak ukur penelitian yang dilakukan.
3. Menentukan Metode Klasifikasi

Berdasarkan permasalahan yang ada, dan bentuk dataset yang merupakan supervised (memiliki label) serta studi literatur yang dipelajari mengenai algoritma yang memiliki akurasi tinggi, metode yang cocok digunakan pada penelitian ini adalah Neural Network karena merupakan salah satu metode prediksi yang akurasinya cukup tinggi dan apabila ditambahkan data set yang lebih banyak tingkat akurasinya akan meningkat.

\section{Pengolahan Data Awal (Pre Processing)}

Data set sebesar 90 data dari data cryotherapy yang di dapat dari UCI Repository akan ditransformasikan untuk mendapatkan data yang benar-benar sesuai dengan format input algoritma Neural Network dengan kriteria input data untuk rapid miner 9.0.

5. Menerapkan Metode Learning dan Testing Menggunakan Neural Network

Proses pertama metode ini yaitu proses learning atau pembelajaran yaitu dengan cara menghitung nilai prediksi data pada waktu terdahulu. Sebelum proses learning data nilai cryotherapy akan di proses terlebih dahulu untuk mengetahui apakah dalam data ada nilai nominal atau tidak, apabila ada maka ubah nilai nominal menjadi numerik karena ada boost tidak dapat membaca nilai nominal. Pada tahap ini data hasil pengolahan antara training menggunakan Neural Network dan learning menggunakan Neural Network (backpropagation) kemudian di testing guna mengukur berapa akurasi trend dari prediksi.

6. Menerapkan Metode Evaluasi dan Validasi Hasil

Evaluasi digunakan untuk melakukan pengamatan dan menganalisa hasil kerja Neural Network pada Rapid Miner. Validasi dilakukan untuk melakukan pengukuran hasil prediksi.

a. Cross Validation

Merupakan pengujian standar yang dilakukan untuk memprediksi error rate. Setiap kelas pada dataset harus diwakili dalam proporsi yang tepat antara data training dan testing. Data dibagi secara acak pada masing-masing kelas dengan perbandingan yang sama. Untuk mengurangi bias yang disebabkan oleh sampel tertentu, seluruh proses training dan testing diulangi beberapa kali dengan sampel yang berbeda. Tingkat kesalahan pada iterasi yang berbeda akan dihitung rata-ratanya untuk 
menghasilkan error rate secara keseluruhan.(Hastuti, 2012).

b. Pengukuran menggunakan ROC Curve

ROC Curve adalah kurva ROC yang banyak digunakan para peneliti untuk menilai hasil prediksi. Kurva ROC menggambarkan kinerja klasifikasi tanpa memperhatikan distribusi kelas atau kesalahan, pada sumbu vertical menggambarkan nilai positif (TP) dan sumbu horizontal menandakan nilai negative (FP). (Sucipto, 2012) Lihat gambar berikut:

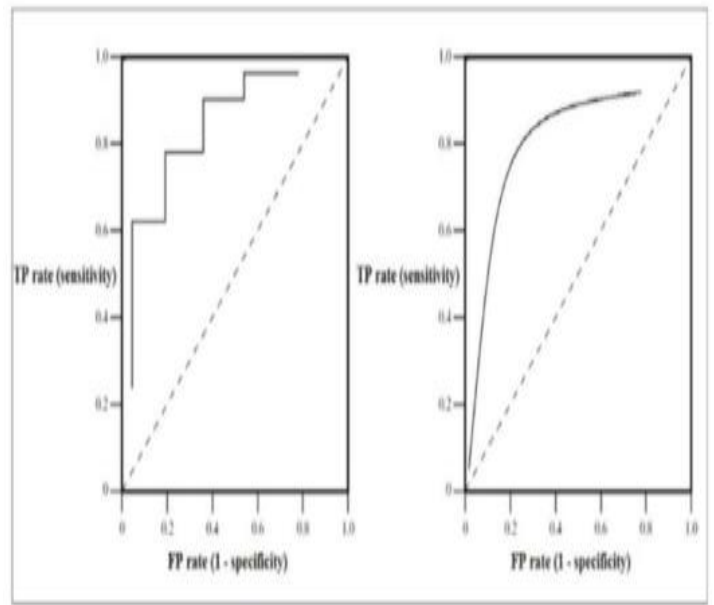

Sumber : (Sucipto, 2012)

Gambar 3. Contoh Grafik ROC

Beberapa hal penting yang perlu dicatat pada Gambar 3., pada titik kiri bawah $(0,0)$ merupakan titik yang tidak pernah mengeluarkan klasifikasi positif, $(1,1)$ terwakili titik kanan atas untuk menjelaskan nilai klasifikasi positif. Titik $(0,1)$ merupakan nilai klasifikasi yang tidak terdapat nilai FN dan FP. Sedangkan garis diagonal yang membelah ruang ROC menggambarkan ruang diatas garis diagonal menandakan klasifikasi baik dan ruang dibawah garis diagonal menandakan klasifikasi buruk, sementara tebakan yang benar-benar acak terdapat pada sepanjang garis diagonal mulai dari kiri bawah sampai dengan kanan atas. (Sucipto, 2012)

Sebuah metode umum untuk menghitng daerah dibawah kurva ROC adalah Area Under Curve (AUC) dimana bidang yang berada dibawah kurve mempunyai nilai yang selalu berada pada nilai 0,0 dan 1,0 . Semakin tinggi luasnya maka akan semakin baik nilai klasifikasinya. Seperti petunjuk yang disajikan berikut ini:

$>0,90-1,00=$ klasifikasi sangat baik

$>0,80-0,90=$ klasifikasi baik
$>0,70-0,80=$ klasifikasi rata-rata

$>0,60-0,70=$ klasifikasi rendah

$>0,50-0,60=$ kegagalan

(Sucipto, 2012).

c. Pengukuran Confusion Matrix

Confusion matrix adalah sebuah tabel yang menyatakan jumlah data uji yang benar diklasifikasikan dan jumlah data uji yang salah diklasifikasikan. (Indriani \& Nbc, 2014)

Contoh confusion matrix untuk klasifikasi biner ditunjukan pada tabel berikut:

Tabel 2.

Confusion Matrix untuk klasifikasi biner

\begin{tabular}{cccc}
\hline & & \multicolumn{2}{c}{ Kelas Prediksi } \\
\cline { 2 - 4 } & & 1 & 0 \\
\hline Kelas & 1 & TP & FN \\
\cline { 2 - 4 } Sebenarnya & 0 & FP & TN
\end{tabular}

Sumber: (Indriani \& Nbc, 2014)

Keterangan untuk Tabel 2. dinyatakan sebagai berikut:

- True Positive (TP), yaitu jumlah dokumen dari kelas 1 yang benar dan diklasifikasikan sebagai kelas 1.

- True Negative (TN), yaitu jumlah dokumen dari kelas 0 yang benar diklasifikasikan sebagai kelas 0 .

- False Positive (FP), yaitu jumlah dokumen dari kelas 0 yang salah diklasifikasikan sebagai kelas 1.

- False Negative (FN), yaitu jumlah dokumen dari kelas 1 yang salah diklasifikasikan sebagai kelas 0 .

Perhitungan akurasi dinyatakan dalam persamaan :

Accuracy $=\frac{(T N+T P)}{(T N+F N+T P+F N)} \times 100 \%$

Sumber: (Indriani \& Nbc, 2014)

\section{Menarik Kesimpulan}

Setelah dataset diolah dan didapat hasilnya secara kuantitatif, maka penulis dapat menarik kesimpulan apakah dataset tersebut dengan klasifikasi 1 berhasil dan 0 untuk gagal mendapatkan akurasi yang tinggi atau tidak, sehingga keberhasilan metode pengobatan cryotherapy dapat diprediksi dengan memperhitungkan parameter yang ada . 


\section{HASIL DAN PEMBAHASAN}

Proses Training, Learning, dan Testing menggunakan Model Neural Network

Proses training, learning, dan testing menggunakan model Neural Network dengan dataset sebanyak 90 data sebagai berikut:

1. Memasukkan data primer ke dalam Read Excel dengan atributnya adalah sex, age, time, number of warts, type, area dan class.

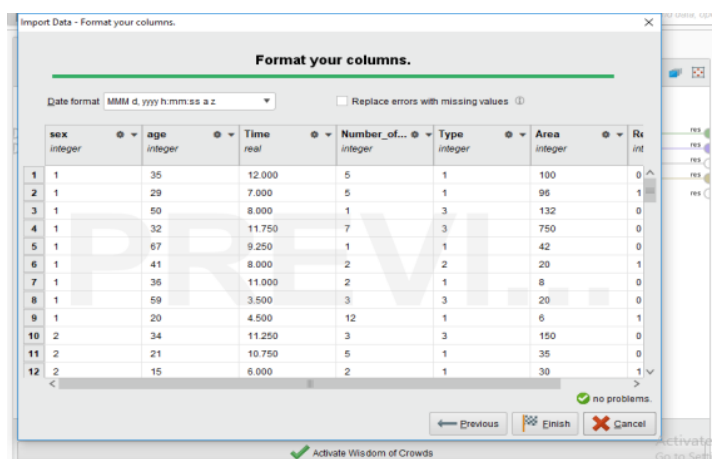

Sumber : (Rahayu et al., 2019)

Gambar 4. Input Dataset

2. Langkah berikutnya adalah pengaturan jenis atribut sesuai dengan algoritma Neural Network. Dalam penelitian ini yang di ubah hanya atribut class menjadi binomal.

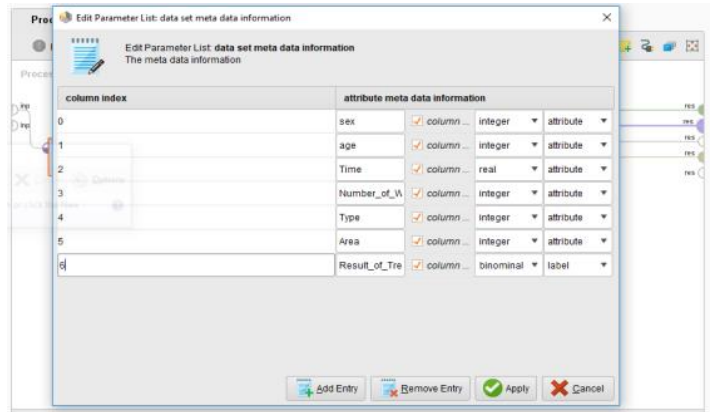

Sumber : (Rahayu et al., 2019)

Gambar 5. Proses Mengatur Atribut

3. Proses insert dan atur validation dengan number of folds 10.

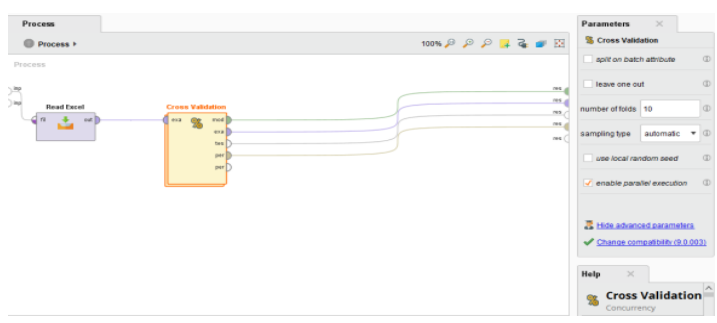

Sumber : (Rahayu et al., 2019)

Gambar 6. Proses Insert dan Atur Validation
4. Proses berikutnya adalah proses insert model yang akan di training, pada proses training kali ini dengan memasukan model algoritma Neural Network dengan menggunakan 90 dataset dengan training cycles 500, learning rate 0,03 dan momentum 0,9 .

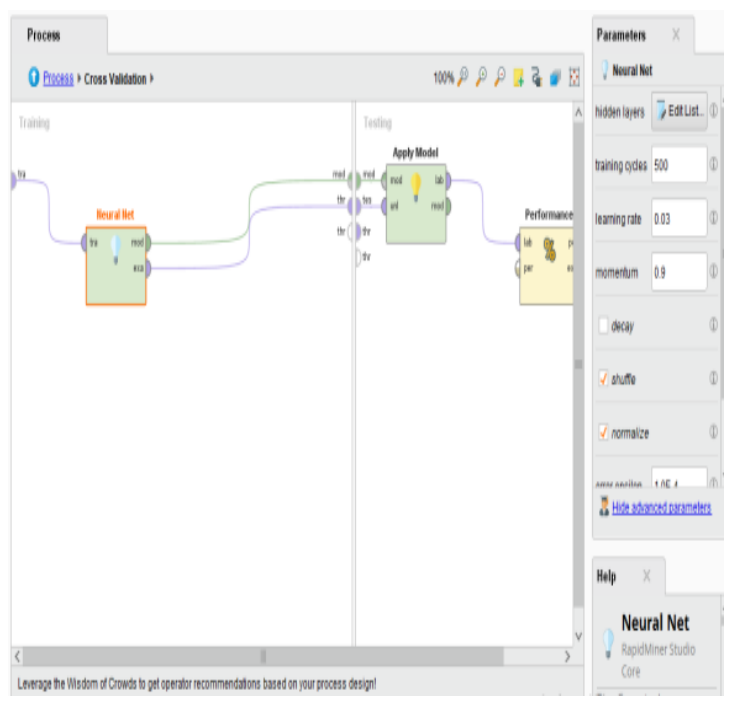

Sumber : (Rahayu et al., 2019)

Gambar 7. Proses Insert Model NN Yang Akan DiTraining

5. Proses terakhir adalah proses testing dengan cara insert apply model performance dengan main criterion accuracy dan AUC.

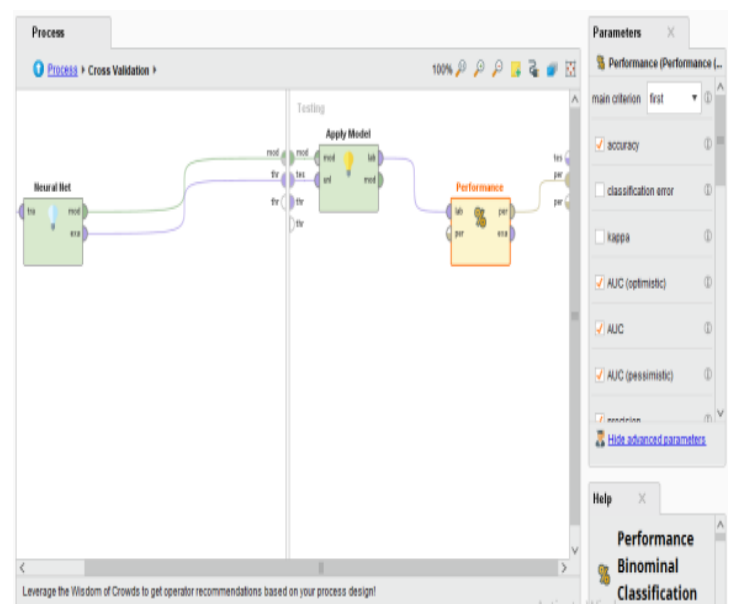

Sumber : (Rahayu et al., 2019)

Gambar 8. Proses Testing Dengan Cara Insert Apply Model dan Performance

6. Hasil testing menunjukan performance accuracy yang dihasilkan menggunakan algoritma Neural Network sebesar 87,78\% dan nilai AUC sebesar 0,955. 
7. Setelah proses testing dengan apply model dan performance didapatkan model hasil pengujian Neural Network.

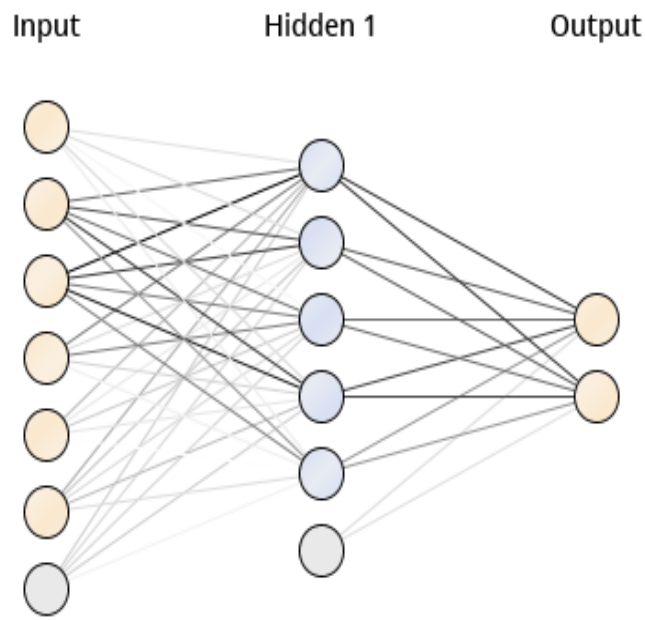

Sumber : (Rahayu et al., 2019)

Gambar 9. Model Hasil Pengujian Neural Network

\section{Evaluasi dan Validasi}

Penelitian ini bertujuan untuk menguji akurasi dari analisa tingkat keberhasilan cryotherapy menggunakan algoritma neural network data yang dianalisa adalah data cryotherapy yang di peroleh dari UCI Repository. Dengan bantuan rapid miner ternyata dapat diketahui algoritma neural network mempunyai akurasi yang tinggi.

\section{Uji ROC Curve}

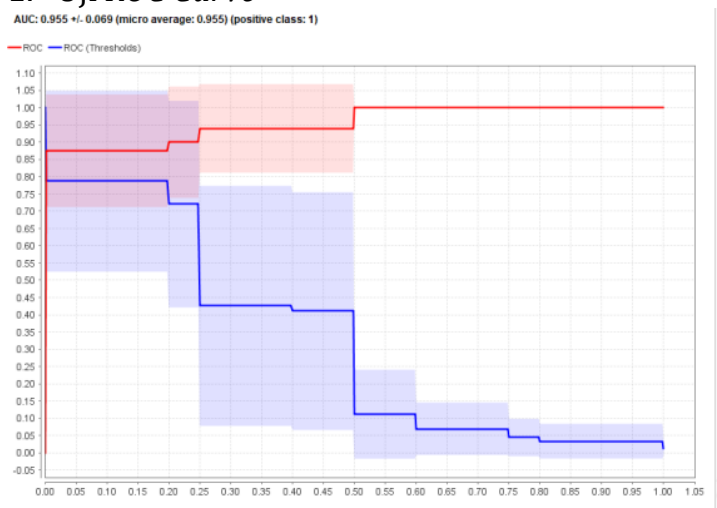

Sumber : (Rahayu et al., 2019)

Gambar 10. AUC Neural Network

Gambar 10. Menggambarkan grafik under curve (AUC) hasil validasi Neural Network dengan hasil AUC sebesar 0,955. Ini menunjukan bahwa hasil akurasi yang diperoleh masuk dalam kategori sangat baik.

\section{Uji Confusion Matrix}

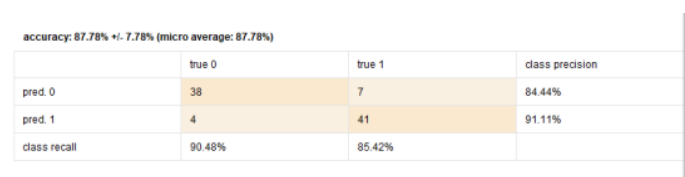

Sumber : (Rahayu et al., 2019)

Gambar 11. Nilai Accuracy dari Neural Network

Berdasarkan Gambar 11. dapat kita ketahui bahwa hasil accuracy dari metode klasifikasi Neural Network sebesar 87,78\% ini menunjukan bahwa hasil akurasi yang diperoleh termasuk kedalam kategori sangat baik.

\section{KESIMPULAN}

Berdasarkan eksperimen yang telah dilakukan dalam penelitian ini, dataset cryotherapy yang didalamnya terdapat parameter-parameter yang menunjukkan kondisi proses terapi es dan class sebagai kondisi berhasil atau tidak, diuji menggunakan algoritma klasifikasi machine learning Neural Network dengan training cycles 500, learning rate 0,03 dan momentum 0,9 menggunakan tools Rapid Miner ternyata menghasilkan akurasi yang tinggi yaitu 87,78\% dan nilai AUC sebesar 0,955 yang artinya termasuk dalam kategori klasifikasi baik sehingga dataset ini dapat menjadi salah satu tolak ukur dalam memprediksi keberhasilan dalam melakukan metode pengobatan cryotherapy.

\section{REFERENSI}

Adil, R., Elektronika, P., \& Surabaya, N. (2005). Pembuatan alat bantu pemantau kondisi tubuh dan keberadaan seseorang saat beraktifitas dengan tampilan web. 1-9.

Andini, W. C. (2018). Cryotherapy , Inovasi Baru untuk Menurunkan Berat Badan. Cryotherapy , Inovasi Baru Untuk Menurunkan Berat Badan, 1-7.

Aulia Adam. (2017). Cryotherapy , Senjata Alternatif Cry Melawan Kanker.

Badrul, M. (2013). PREDIKSI HASIL PEMILU LEGISLATIF DKI JAKARTA DENGAN METODE NEURAL NETWORK BERBASIS PARTICLE SWARM OPTIMIZATION Pendahuluan. PREDIKSI HASIL PEMILU 


\section{LEGISLATIF DKI JAKARTA DENGAN METODE NEURAL NETWORK BERBASIS PARTICLE SWARM OPTIMIZATION, IX(1), 37-47.}

Basarslan, M. S., \& Kayaalp, F. (2018). A Hybrid Classification Example in the Diagnosis of Skin Disease with Cryotherapy and Immunotherapy Treatment. 2018 2nd International Symposium on Multidisciplinary Studies and Innovative Technologies (ISMSIT), 1-5.

Cüvitoğlu, A., \& Işik, Z. (2018). Evaluation Machine-Learning Approaches for Classification of Cryotherapy and Immunotherapy Datasets. 8(4). https://doi.org/10.18178/ijmlc.2018.8.4. 707

Eko Susanto, W., \& Riana, D. (2016). Komparasi Algoritma. 8(3), 18-27.

Hastuti, K. (2012). Analisis komparasi algoritma klasifikasi data mining untuk prediksi mahasiswa non aktif. 2012(Semantik), 241-249.

Indriani, A., \& Nbc, D. (2014). Klasifikasi Data
Forum dengan menggunakan Metode Naïve Bayes Classifier. 5-10.

Khozeimeh, F., Alizadehsani, R., Roshanzamir, M., Khosravi, A., Layegh, P., \& Nahavandi, S. (2017). An expert system for selecting wart treatment method. Computers in Biology and Medicine, 81(January), 167175.

https://doi.org/10.1016/j.compbiomed.2 017.01.001

Rahayu, S., Nugraha, F. S., \& Shidiq, M. J. (2019). Analisa tingkat keberhasilan cryoterapy menggunakan neural network. 14(2), 1-7.

Sucipto, A. (2012). CREDIT PREDICTION WITH NEURAL NETWORK ALGORITHM Ir . Adi Sucipto, M. Kom . Sains and Technology Faculty Universitas Islam Nahdlatul Ulama Jepara. (15), 978-979.

Widowati, L., \& Mudahar, H. (2009). Ujiaktivitas ekstrak etanol 50\% umbi keladi tikus (typhoniumflagelliforme (lood) bi) terhadap sel kanker payudara mcf-7 in vitro. XIX, 3-8. 